\title{
The Moral Status of Animal Research Subjects in Industry: A Stakeholder Analysis
}

\author{
Sarah Kenehan \\ Associate Professor, Philosophy Department, Marywood University, \\ Pennsylvania, United States
}

The use of non-human animals (hereinafter referred to as animals) in research and testing is a widely accepted practice in many industries. Millions of animals each year are subjected to painful procedures that include everything from physical mutilation to drug addiction. According to the United States Department of Agriculture (USDA), over 820,812 animals were experimented on in the United States in 2016 (USDA, 2017), though this count does not include rats, mice, or birds, and dubiously relies solely on the self-reporting of laboratories (Humane Society of the United States, 2011; Keen, 2019, Chapter 10 in this Volume). Estimates suggest that a more accurate count - one that includes rats, mice, and birds - brings the number closer to 25 million total animals used in the United States (Humane Society of the United States, 2013). These numbers raise many questions, not least of which is whether this practice is prima facie immoral. But this is not the broader question that I address in this chapter. Instead, I look at the continued use of animals for experiments from the point of view of business ethics, in particular, through the lens of stakeholder theory. Specifically, I argue that animals as research subjects are stakeholders in the corporations that practice animal experimentation, and this status demands that their interests be considered with the interests of other stakeholders.

Importantly, while this chapter discusses issues of interest to a broader philosophy audience, it is, nonetheless, situated in a volume whose purpose is, in part, to motivate practical paradigm change in the way that animal advocates think about their work. Not unlike other scholars, my own work is shaped by my personal experiences: I am a philosopher by training and an animal advocate outside the walls of the academy, so my concern for animals is both theoretical and pragmatic. As such, the practical import of this chapter speaks most obviously to people like me, i.e., advocates who are also academics. In particular,

(C) SARAH KENEHAN, 2019 | DOI:10.1163/9789004391192_009 
arguing for the stakeholder status of animals in research corporations gives advocates (both academic and traditional) a new tool to use in the fight for the proper consideration of animal interests. It brings the conversation-in an organic and relevant way - to a group of people who would have likely remained uninformed of the issue, and offers defenders of animal interests the opportunity to employ a general method of advocacy that has historically been very successful.

The argument in this chapter proceeds as follows. To begin, I discuss the broad and narrow interpretations of the stakeholder view, and I argue that the narrow view offers a more practical framework for making business decisions. Following this, I will show that, while no iteration of stakeholder theory ever directly identifies animals as stakeholders, the inclusion of research animals in this category is as self-evident as the inclusion of employees; minimally, this demands that the moral manager properly considers the interests that research animals have in not suffering. I then contend that if research animals really are stakeholders, and if their interests really are more urgent than the interests of other stakeholders, then the presumed legitimacy of animal experimentation needs to be reevaluated. Finally, in the last section I offer some responses to three potential objections to the arguments put forth in this chapter. Ultimately, I conclude that, from the point of view of stakeholder theory, animal experimentation, especially when it inflicts suffering on animal subjects, is not justifiable.

\section{Narrow and Broad Interpretations of the Stakeholder View}

Stakeholder theorists claim that the purpose of the corporation is to harmonize the interests of the stakeholders, though there is not widespread agreement on how to identify stakeholders (Goodpaster, 1991, p. 66). Indeed, Mitchell et al. (1997) have catalogued 27 different conceptions of the stakeholder, including some of the following:

A stakeholder is/stakeholders are:

- a person or group, "which the organization is dependent on for its continued survival” (Freeman and Reid, 1983, p. 91; Mitchell et al., 1997, p. 858)

- a person or group, "that benefit[s] from or are harmed by, and whose rights are violated or respected by, corporate actions." (Evan and Freeman, 1988, p. 79; Mitchell et al., 1997, p. 858)

- "constituents who have a legitimate claim on the firm [...] established through the existence of an exchange relationship" and who supply "the firm with critical resources (contributions) and in exchange each expects 
its interests to be satisfied" (Hill and Jones, 1992, p. 133; Mitchell et al. 1997, p. 858)

- a person or group "having some legitimate, non-trivial relationship with an organization [such as] exchange transactions, action impacts, and moral responsibilities" (Brenner, 1993, p. 205; Mitchell et al., 1997, p. 858)

- "the firm is significantly responsible for their well-being, or they hold a moral or legal claim on the firm" (Langtry, 1994, p. 433; Mitchell et al., 1997, p. 858)

- and "persons or groups with legitimate interests in procedural and/or substantive aspects of corporate activity." (Donaldson and Preston, 1995, p. 85; Mitchell et al., 1997, p. 858).

The most frequently cited stakeholder theorist, Edward Freeman (1984), describes a stakeholder as "any group or individual who can affect or is affected by the achievement of the organization's objectives" (p. 46). Of course, like many of the others, this definition is vague, and much is left to interpretation. But, broadly construed, this definition commonly includes the government, the environment, and many third-party associations (e.g., the suppliers of a supplier), in addition to the commonly recognized stakeholder groups: owners, suppliers, employees, customers, and local community. On this, the wide interpretation, the category of stakeholder is quickly rendered unruly and insignificant, as it can be expanded to include just about any person or group (for the origin of this distinction, see Freeman and Reed, 1983). As Orts and Strudler (2002, p. 218) note, "virtually anyone and anything can 'affect or be affected' by the decisions and actions of business enterprise. Expansive views of relevant 'stakeholders' tend easily to become so broad as to be meaningless and so complex as to be useless." Clearly then, we are in need of a refined understanding of the concept of stakeholder.

One such definition proposes that stakeholders be identified as those groups, "who are vital to the survival and success of the firm" (Evan and Freeman 1998, p. 58), or who are "definitional to the firm" (Freeman et al., 2002, p. 31). According to this narrow view, stakeholders are much easier to identify, thus, making this view more workable from a management standpoint. Surely, though, one might argue that by limiting the account of stakeholders to the narrow interpretation, we risk overlooking groups and entities that deserve consideration when business decisions are made. But, importantly, stakeholder status is not the sole identifier of moral considerability. For example, Orts and Strudler (2002, p. 221) state that businesses have moral obligations to obey the law, even if it conflicts with stakeholder interests.

Of course, neither the narrow nor the wide view of stakeholder identification is without its difficulties. The most obvious difficulty, for both, is that 
regardless of how stakeholders are identified, complications arise in balancing the claims and interests of the various stakeholder groups, as stakeholder identification alone does not address which claims or interests are the most important, at what time. Nonetheless, going forward, I adopt a narrow interpretation of stakeholder identification, as the broad view renders the moral manager impotent in their decision-making. Indeed, the narrow view is most widely defended by stakeholder theorists and is most widely adopted by managers (e.g., see Mitchell et al., 1996, and references therein). Even so, it is not the purpose of this chapter to defend one conception of stakeholder identification over another. Rather, my goal is much less lofty: it is simply to show that even according to the narrow conception of stakeholder (and so presumably also the wide conception), animals who are experimented on can be properly construed as stakeholders in the corporations that conduct these experiments. As such, their interests cannot be disregarded.

\section{Research Animals, Stakeholders, Suffering, and Compassion}

\section{1}

\section{Research Animals as Stakeholders}

As noted, the narrow interpretation of stakeholder restricts stakeholders to those groups "who are definitional to the firm" (p. 31, Freeman et al., 2002). This interpretation is commonly thought to include customers, suppliers, financiers, employees, and parts of the local community. However, given the fact that many businesses rely heavily on research animals to bring products to market, then these animals are very likely stakeholders too, analogous to suppliers and/or employees. Consider, for instance, the use of animals in the Draize eye irritancy test, an experiment that is used by an array of companies to evaluate how irritating a particular substance is. (Notably, the use of this test has decreased, as it was banned for use in cosmetics testing in the $\mathrm{EU}$, India, Israel, and New Zealand, though it is still used quite often in the us and elsewhere (Cruelty Free International, 2017). In this test, animals (typically rabbits) may be unable to move for days while chemicals are applied to their eyes, and usually the animal subjects are given no more than a topical anesthetic, so long as it does not interfere with the experiment. Sometimes these tests result in infection and/or tissue damage that is so severe that the animal is rendered blind (Humane Society International, n.d.). If these animals cannot be re-used in future tests (because of the damage done by previous tests) they are killed, usually by being suffocated, having her neck broken, or by being decapitated (Humane Society of the United States, 2018). Without the information this test supplies, many companies would be unwilling or unable to bring their products to market. Therefore, it may be said that the animals on 
whom the Draize test and other such tests rely are central to the successes of the companies that depend on these practices.

Like human employees, research animals offer a very specific type of labor, without which the company would potentially suffer severe financial penalties. These animals are sometimes subjected to painful tests for years at a time without any form of relief or compensation. They are forced to give their freedom, their health, their well-being, and their lives to these companies. And like the suppliers of a company, animal subjects of experimentation provide the business with the raw materials and services that it needs to make its product; but in the case of the laboratory animals, the materials that are being supplied are the bodies and lives of the animal subjects. Without these "materials", companies would not be able to perform the Draize tests or similar experiments. As such, research animals are stakeholders, even on the narrow conception, in the companies that use them. They are, like an employee or supplier, integral to the operations of the firm, and so, accordingly, their interests must be considered as any other stakeholder's interests would.

Importantly, establishing that research animals are stakeholders does not help in the identification of the relevant interests deserving of consideration, nor does it tell us how to balance these interests against other stakeholder claims; though, to be clear, this ambiguity does not mean that we are justified in subordinating non-human animal interests to human interests. There are likely to be many workable routes for identifying and managing stakeholder interests, but for brevity, I focus on one possible way to identify the interests that matter in this context, and I will likewise propose one way that we might commensurate the interests of competing stakeholder groups.

\subsection{Commensurating Stakeholder Interests: Suffering and Compassion}

The phrase to have an interest means that something (A) has welfare or well-being, such that, "having or doing $\mathrm{X}$ would (or we think it would) benefit $\mathrm{A}$, that having or doing $\mathrm{X}$ would make a contribution to A's well-being" (Regan, 1983, p. 88). Based on this understanding, animals, at the very least, have a basic and fundamental interest in not suffering, and they probably also have interests in enjoying their lives and avoiding untimely deaths (though, for the purpose of this chapter, I refrain from relying on the latter two). The interest in not suffering is, as Singer and Bentham point out, a prerequisite for having any other interests, and so it is prior to and more urgent than any other interests (Singer, 2002, p. 7). This establishes one possible way to balance stakeholder interests: the more foundational and urgent the interest, the more heavily it is weighted. To be sure, the experiments that animals are subjected to in research laboratories are directly and obviously contrary to their interest in not suffering. Furthermore, given the fundamental nature of this 
interest, and the systematic way in which it is violated, its proper consideration is likely much more urgent and pressing than the consideration of other legitimate stakeholder concerns and so should be prioritized by the decision maker.

Of course, it might be argued that engaging in medical research in which animals are used as test subjects helps us to take account of a sick person's interest in not suffering, an interest that may be just as urgent as the interest of the laboratory animal. Let us assume for the sake of argument that this is true, i.e., that medial research on animals is the only way in which the cures and treatments for some illnesses will ever be discovered. If this is the case, then when we choose not to engage in animal research, are we then also choosing to ignore the interest that sick people have in not suffering? Put in the context of business ethics, the moral manager may be torn between causing suffering to animals and potentially preventing suffering that would otherwise happen to humans, and refusing to impose suffering on animals but allowing sick people to suffer. This is a complex moral issue, but one possible way to navigate through this terrain is to think about those qualities that we would expect the moral manager to have and then explore how those qualities may direct them in this situation.

Surely, one important quality of the moral manager would be compassion. Indeed, Solomon (1999, Chapter 3) lists compassion as one among many of the business virtues, explaining that the directive of compassion is to relieve suffering: "Within the corporation, compassion is often called for [...] Compassion, of course, can be expensive [...] but what is less obvious is the enormous expense of not having or expressing compassion, in further lost time and the distraction that comes of suffering through hardship alone, in the insecurity and consequent lack of devotion of not only the employee in question but of everyone around, in seething resentment. Compassion, like caring, is not merely a humanizing embellishment in the otherwise businesslike life of a corporation. It is essential to the very life of that corporation as a human community." While Solomon beautifully articulates the importance of compassion towards employees as humans, notably absent from this characterization is concern for animal suffering. It is unclear how Solomon thinks that the moral manager should consider animals' interests in not suffering, but regardless of Solomon's own position, the principle of equality requires that, "suffering be counted equally with like suffering - in so far as rough comparisons can be made-of any other being" (Singer, 2008, p. 37). This is a basic principle of fairness, and to violate it on the basis of one's race, gender, or even species would be arbitrary and wrong. Therefore, the moral manager should be concerned not just with the suffering of the humans in their corporate community, but 
also with the animals in their corporate community; this is what fairness and compassion demand.

So, the question is now: Can the virtue of compassion help us to mitigate the conflict between the human interest in not suffering and the animal interest in not suffering, as described above? I think so. Consider this dilemma, as explored by Simmons (2016, p. 113):

What is the compassionate thing to do in this case? It seems ambiguous since one can be compassionate to humans by promoting their interests in continued life. I contend, however, that to refrain from killing animals, even at the potential cost of failing to benefit human health, is the more fully compassionate thing to do. To kill animals in order to save human lives entails offensively (i.e., aggressively) and intentionally causing harm to others without their consent. Indeed, it is an act of aggression, violence, and domination, even if done to help others [...] [T]o intentionally, offensively inflict harm on another shows, to some degree, a lack of concern for the other's welfare [...] On the other hand, to refrain from killing animals, at the potential cost of not saving human lives, need not show any lack of concern for human welfare. It is not offensively causing harm to humans; it is merely failing to help them.

Importantly, Simmons (2016) argues that failing to mitigate the harms suffered by the humans that result from their diseases is not actually the result of moral indifference, nor the result of intentionally wanting the humans to suffer. Instead, "A fully compassionate person aims to prevent harm to individuals but will not offensively, intentionally inflict harm on others in the process of doing so" (p. 114). If Simmons is correct, then the moral manager will not allow the infliction of suffering on animals for the sake of preventing human suffering.

Of course, the case above assumes that there will always be a conflict between the animal interest in not suffering and the human interest in not suffering. But, this is a false dichotomy. This supposed conflict rests on two assumptions: first, that medical research nearly always results in cures or treatments that can effectively alleviate human suffering; and second, that the relief of human suffering can only be achieved by inflicting suffering on animals. Neither of these assumptions is valid. Research has actually shown that animal experiments done with the purpose of extrapolating results relevant to human health are notoriously ineffective. Pharmaceuticals tested on animals have a 90\% failure rate (Pharmaceutical Research and Manufacturers of America, 2015; 2016); this means that they are certified safe from animal studies, then fail in human clinical trials or once they reach the market. Additionally, there 
are many non-animal testing methods that can be used in place of animal experimentation. These include, but are not limited to: epidemiological studies (studies of human populations); clinical research; bioinformatics (statistical evaluation of biology); systems biology (studies of interaction between biological systems); tissue engineering (a combination of engineering principles and biology); microfluidics (organ on a chip); in vitro (human cell and tissue cultures) research; in silico (computer-based) techniques; stem cell methods; genetic methods; advanced imaging technologies; and safe human-based studies (see Chapters in Part 7 in this Volume: Hartung, 2019; Noor, 2019; Taylor, 2019; Wilkinson, 2019). As such, there are ways to relieve human suffering that do not demand that we inflict suffering on animals. We can conclude, then, that it is unlikely (though not impossible) that the interest humans and nonhuman animals have in not suffering will not conflict as obviously or as regularly as commonly thought.

\subsection{Summary}

In this section I have argued that, by definition, research animals can be categorized as stakeholders in businesses that engage in animal experimentation or testing. In most cases of animal experimentation, the interest being violated is the animal's interest in not suffering, an interest that is, more often than not, more urgent than the interests of competing stakeholders. And, furthermore, in taking the virtue of compassion seriously, the moral manager can mitigate conflicts that arise between two groups of stakeholders that may both have an interest in not suffering; in particular, compassion demands that we do not intentionally cause harm to one group, even if we do it to prevent harm to another group. As such, stakeholder theory demands that, at a minimum, managers have a moral imperative to stop animal experimentation that inflicts suffering on animal subjects.

In this final section, I address some potential objections to my argument.

Objection 1: Aren't There Laws in Place that Already Protect the Interests of Animal Subjects?

Those familiar with the practice of animal experimentation may be tempted to claim that advocating for the interests of animals as stakeholders is unnecessary, since there are already laws and regulations in place that serve 
to protect the interests of animal subjects. One such law, in the Us, is the US Animal Welfare Act (AWA) (1966, last amended 2013). In fact, the AWA does set minimal requirements for the care of certain animal species used in laboratories, ensuring that they have water, food, and shelter. Even so, these minimal standards fail to adequately protect an animal's interest in not suffering; and further, simple adherence to the AWA is not an appropriate tool for gauging if an animal's interest in not suffering has actually been respected. To begin, the Act only demands adequate food, shelter, and water be provided outside the demands of the experiment; that is, as a matter of experimentation, animals can be denied these things and, worse, for sustained periods of time. Indeed, it is not uncommon for animals to be subjected to radiation exposure; shock therapy; exposure to nerve gas; mutilation; social isolation; drug overdose and addiction; starvation and dehydration; oxygen deprivation; surgery without anesthesia; poisoning; induction of psychopathology, including depression (in higher primates); deprivation studies; extreme temperature exposure; toxicity tests; and immersion and injection studies (Singer, 2002, Chapter 2). Second, the Act does not cover mice, rats, birds, or reptiles; so, these animals - the animals who comprise the majority of laboratory animals-are not guaranteed any protections (US Animal Welfare Act, 1966, last amended 2013). And finally, the Act presumes that experimentation on animals is actually acceptable, thus subordinating the interests of animals from the outset, as do all similar regulations. Clearly then, simply adhering to the Animal Welfare Act (or similar rules in other countries) does not guarantee that a company has rightfully considered the interests of its animal test subjects. As such, there is good reason to identify research animals as stakeholders.

\subsection{Objection 2: What About the Other Stakeholders?}

What if taking this argument seriously meant that a company had to shut its doors? This is an important concern, but I think we can address it by first thinking about a less controversial case. Consider a world in which multi-national corporations that rely on child labor were forced to actually take the interests of their child laborers into consideration, minimally, the children's interests in not suffering. For some corporations, taking these interests seriously may only require making some changes, e.g., finding new laborers, relocating plants, removing some products from the market. But for other corporations, respecting these interests may mean that they have to halt their operations completely. Would we, should we, object to these closures? In doing so, would we not be saying that the protection of the fundamental interests that the children have in not suffering (among other interests) is not as important as the survival of 
the corporation? This seems to be an indefensible claim: a concern for maximizing profits does not trump all other concerns. This is not to say that the profit interests of the other stakeholders are not important or serious, but rather, the urgency of the interests being violated in this case gives priority to the children. Put more generally, in instances in which there is a serious and systematic violation of basic interests, we should be comfortable with the closure of companies that rely on these violations for their continuation. This holds whether the interests in question stem from human or non-human stakeholders, as fairness demands that we give equal consideration for equal interests.

Of course, this assumes that the animal experimentation and financial success are necessarily linked, meaning that corporations will disappear without the ability to engage in animal experimentation. But, this is absolutely not the case, since viable alternatives to animal testing exist or can be developed. In fact, many companies have already moved towards this change (many were forced in this direction as a result of the $\mathrm{EU}$ ban on cosmetics implemented in 2013). And even other companies have, from their inception, made it part of their mission statement to avoid cruel animal experimentation. The continued success of such companies (and the industries in which they are situated) shows that businesses can remain financially viable without experimenting on animals. So, forgoing animal experimentation does not necessitate that a business close its doors, and this means that the reduction and eventual elimination of animal experimentation would not necessarily conflict with the interests that the other stakeholders have in the financial success of their corporations.

Objection 3: Why Business Ethics? (Or, What is the Practical Import of this Argument for the Animal Advocate?)

One might wonder what value a business ethics approach to this issue offers, given that so many moral theorists have already convincingly argued that animal experimentation is, in most cases, wrong (e.g., DeGrazia, 1996; Regan, 1983; Singer, 2002). Likewise, animal advocates may wonder how this argument practically advances the movement to see the interests of research animals properly protected. As an academic and an advocate, I see these two concerns as inextricably linked, and I strongly believe that the stakeholder approach to considering animal interests is a tool that can be employed in the academy and in the social/political space where traditional advocacy occurs.

Perhaps, unsurprisingly, I agree that there are many compelling arguments that successfully condemn the practice of animal experimentation. Even so, there are several reasons why framing this issue from the point of view of business ethics can be helpful. First, it seems quite obvious-especially in light of 
the arguments developed above-that laboratory animals are stakeholders in the institutions that practice animal experimentation. And yet, nowhere in the vast stakeholder literature are these particular animals referenced or acknowledged. Occasionally, a theorist will consider the possibility of the environment as a stakeholder, and so by default the wild animals who live in the environment become stakeholders in a way, but animals confined to a life in a laboratory are never mentioned (e.g., Bowie, 2009; Orts and Strudler, 2002). This seems to me a serious oversight, and so, academically, this subject deserves consideration. But, beyond the rather obvious scholarly omission, business students are unlikely to be taught animal ethics in business school, and it is similarly unlikely that they are required to take courses in ethical theory. Instead, they may be required to take a course in business ethics, where they study stakeholder and stockholder theory, the various forms of contracts, sexual harassment/ discrimination, and the like. These issues are undoubtedly important; however, given the moral urgency surrounding the practice of animal experimentation, it is likewise very important to discuss the rightness or wrongness of using animals as test subjects, especially with those who will be in a position to benefit from the practice. Notably, discussing the morality of animal experimentation by exploring the argument that animals are stakeholders allows, in a very natural and cohesive way, business students to think about the use of animals as test subjects, using language and ideas that they are already familiar with and comfortable using, and so this approach offers business students both substantive and directive guidance in considering animal interests. Furthermore, exposing business students to this way of thinking is crucially important, since, in the very near future, many of them may be in a position to make decisions that reflect a real moral concern for animal subjects in a way that other people will never have the opportunity to do (there are only so many of us that will manage laboratories and the like). Thus, I see this argument as giving the academic advocate a route to introducing concern for laboratory animals in a way that utilizes a framework that is already accepted by the typical business student.

In addition, it is also worth noting that, historically speaking, the general method of arguing for stakeholder status is typically a part of any successful route to having an oppressed or exploited group's interests properly considered. Even if the technical language of stakeholder is not employed, one way to interpret the historical inclusion of many stakeholder groups is as a fight to have stakeholder status properly recognized. Several examples fit this characterization, including the restriction on child laborers in the late Industrial Revolution and, more recently, the movement to properly recognize the interests of adjunct professors at universities in the us (at some institutions, at least). In these cases and others like them, the moral arguments for 
stakeholder status preceded the adoption of legal safeguards that formalized limits on what could be done to these groups in the name of maximizing profits. Many students of business are taught not just to respect these limits legally, but to understand why they are so important. Indeed, many such principles are built into professional codes of ethics and corporate mission statements, both of which help to influence corporate cultures and set expectations for managers. This general sort of social evolution gives us good reason to believe that classifying animals as stakeholders can be understood as a natural extension of the principles and guidelines that many business people and corporations already adhere to and endorse, and that real protections for research animals (as real protections for any other stakeholder group) do not necessarily have to be interpreted as completely and arbitrarily contrary to the profitability of the business.

Finally, and perhaps obviously, my argument could easily be extended to corporations that raise animals for food or use animals in entertainment; any use of animals for the sake of profit-making automatically qualifies them as stakeholder, and so, as such, they should be afforded the rights and considerations of these groups. This means that the case made above will have applicability for animal advocates in ways that extend far beyond the moral and legal consideration of animals used for research and testing.

\section{5}

\section{Conclusion}

I have argued that research animals are analogous to a company's employees and/or suppliers and can thus be considered stakeholders according to the narrow conception of stakeholder identification. If this categorization is correct, then businesses have an obligation to consider the interests of these animals, including, minimally, their interests in avoiding suffering. In addition, I have argued that the interest in not suffering is very likely more urgent and fundamental than the legitimate interests of the other stakeholder groups and so should be treated as such. Therefore, according to stakeholder theory, corporations should refrain from using animals as test subjects, especially when such testing inflicts suffering on the animal subjects. Moreover, beyond offering an interesting theoretical claim, the arguments in this chapter give advocates (both academic and traditional) a new tool to use in the fight for the proper consideration of animal interests by making the issue relevant to a broader audience. It brings the conversation in a pertinent and topical way to a group of people who would have likely remained uninformed of the topic and offers advocates the opportunity to employ a method of advocacy that 
has historically been very successful. There are, then, both moral and practical reasons for including research animals as stakeholders in corporations that engage in animal research and testing.

\section{References}

Bowie, N. (2009). Morality, money, and motor cars. In: T. Beauchamp, N. Bowie, and D. Arnold, eds., Ethical Theory and Business, 8th ed. Upper Saddle River: Prentice Hall, pp. 516-523.

Brenner, S.N. (1993). The Stakeholder Theory of the Firm and Organizational Decision Making: Some Propositions and a Model. In: J. Pasquero and D. Collins, eds., Proceedings of the Fourth Annual Meeting of the International Association for Business and Society. San Diego, pp. 853-886.

Cruelty Free International (2017). We call on United Nations for a Global Ban on Animal Testing for Cosmetics. [online] Available at: https://www.crueltyfreeinternational. org/what-we-do/breaking-news/we-call-united-nations-global-ban-animaltesting-cosmetics [Accessed 1 August 2018].

DeGrazia, D. (1996). Taking Animals Seriously: Mental Life and Moral Status. Cambridge: Cambridge University Press.

Donaldson, T. and L. Preston (1995). The Stakeholder Theory of the Corporation: Concepts, Evidence, and Implications. Academy of Management Review, 20(1), pp. 65-91.

Evan, W.M. and E. Freeman (1988). A stakeholder theory of the modern corporation: Kantian Capitalism. In: T. Beauchamp and N. Bowie, eds., Ethical Theory and Business, 3rd ed. Englewood Cliffs: Prentice Hall, pp. 97-106.

Freeman, E. and D. Reed (1983). Stockholders and Stakeholders: A New Perspective on Corporate Governance. California Management Review XXV(3), pp. 88-106.

Freeman, E., T.M. Jones and A. Wicks (2002). Stakeholder theory: The state of the art. In: N. Bowie, ed., The Blackwell Guide to Business Ethics. Malden: Blackwell Publishers, pp. 19-37.

Freeman, R. (1984). Strategic Management: A Stakeholder Approach. Boston: Pittman.

Goodpaster, K. (1991). Business Ethics and Stakeholder Analysis. Business Ethics Quarterly, 1(1), pp. 53-73.

Hartung, T. (2019). Research and testing without animals: where are we now and where are we heading? In: K. Herrmann and K. Jayne, eds., Animal Experimentation: Working Towards a Paradigm Change, Vol. 22. Brill Human Animal Studies Series, pp. 675-69o. Leiden: Brill.

Hill, C. and. T. Jones (1992). Stakeholder-Agency Theory. Journal of Management Studies, 29(2), pp. 131-154. 
Humane Society International (n.d.). Rabbits: Blinded for Beauty. [online] Available at: http://www.hsi.org/assets/pdfs/rabbits_blinded.pdf [Accessed 1 August 2018].

Humane Society of the United States (2018). Fact Sheet: Cosmetic Testing. [online] Available at: http://www.humanesociety.org/issues/cosmetic_testing/qa/questions _answers.html [Accessed 1 August 2018].

Keen, J. (2019). Wasted money in United States biomedical and agricultural animal research. In: K. Herrmann and K. Jayne, eds., Animal Experimentation: Working Towards a Paradigm Change, Vol. 22. Brill Human Animal Studies Series, pp. 244272. Leiden: Brill.

Langtry, B. (1994). Stakeholders and the Moral Responsibilities of Business. Business Ethics Quarterly, 4(4), pp. 431-443.

Mitchell, R., A. Bradley and D. Wood (1997). Toward a Theory of Stakeholder Identification and Salience: Defining the Principle of Who and What Really Counts. The Academy of Management Review, 22(4), pp. 853-886.

Noor, F. (2019). The changing paradigm in preclinical toxicology: in vitro and in silico methods in liver toxicity evaluations. In: K. Herrmann and K. Jayne, eds., Animal Experimentation: Working Towards a Paradigm Change, Vol. 22. Brill Human Animal Studies Series, pp. 612-640. Leiden: Brill.

Orts, E. and A. Strudler (2002). The Ethical and Environmental Limits of Stakeholder Theory. Business Ethics Quarterly, 2(2), pp. 215-233.

Pharmaceutical Research and Manufacturers of America (PhRM) (2015). Biopharmaceutical Research Industry Profile. Washington, DC: PhRMA. http://phrma-docs .phrma.org/sites/default/files/pdf/2015_phrma_profile.pdf [Accessed 1 August 2018].

Pharmaceutical Research and Manufacturers of America (PhRM) (2016). Biopharmaceutical Research Industry Profile. Washington, DC: PhRMA. http://phrma -docs.phrma.org/sites/default/files/pdf/biopharmaceutical-industry-profile.pdf [Accessed 1 August 2018].

Regan, T. (1983). The Case for Animal Rights. Berkley: University of California Press.

Simmons, A. (2016). Do all subjects of a life have an equal right to life? The challenge of the comparative value of life. In: M. Engel and G.L. Comstock, eds., The Moral Rights of Animals. Lanham: Lexington Books, pp. 107-117.

Singer, P. (2002). Animal Liberation. Updated edition, New York: Harper Collins.

Singer, P. (2008). Practical Ethics. In: S. Armstrong and R. Botzler, eds., The Animal Ethics Reader, 2nd ed. New York, Routledge, pp. 36-46.

Solomon, R. (1999). A better way to think about business: how personal integrity leads to corporate success. Oxford: Oxford University Press.

Taylor, K. (2019). Recent developments in alternatives to animal testing. In: K. Herrmann and K. Jayne, eds., Animal Experimentation: Working Towards a Paradigm Change, Vol. 22. Brill Human Animal Studies Series, pp. 587-611. Leiden: Brill. 
The Humane Society of the United States. (2011). United States Department of Agriculture Animal and Plant Health Inspection Service, annual report animal usage by fiscal year, 2011. [online] Available at: http://www.aphis.usda.gov/animal_welfare/efoia/ downloads/2010_Animals_Used_In_Research.pdf [Accessed 1 November 2014].

The Humane Society of the United States. (2013). Questions and answers about biomedical research. [online] Available at: http://www.humanesociety.org/issues/biomedical_research/qa/questions_answers.html [Accessed 1 November 2014].

Us Animal Welfare Act (AWA) (1966, last amended 2013), 7 U.S.C. § 2131. United States Department of Agriculture. [online] Available at: https://www.nal.usda.gov/awic/ animal-welfare-act [Accessed 1 August 2018].

USDA (2017). Annual Report Animal Usage by Fiscal Year [online] Available at: https:// www.aphis.usda.gov/animal_welfare/downloads/reports/Annual-Report-AnimalUsage-by-FY2016.pdf [Accessed 1 August 2018].

Wilkinson, M. (2019). The potential of organ on a chip technology for replacing animal testing. In: K. Herrmann and K. Jayne, eds., Animal Experimentation: Working Towards a Paradigm Change, Vol. 22. Brill Human Animal Studies Series, pp. 641-655. Leiden: Brill. 